\title{
O wielkości i trudnościach polskiej transformacji
}

\author{
Uwagi w związku z książką Tadeusza Mazowieckiego \\ Rok 1989 i lata nastepne. Teksty wybrane i nowe, \\ Wydawnictwo Prószyński i S-ka, Warszawa 2012, ss. 504
}

Obszerny tom wybranych szkiców, przemówień oraz wywiadów z ostatniego ćwierćwiecza można uznać za publiczny testament zmarłego 28 października 2013 r. Tadeusza Mazowieckiego. Zgodnie z tytułem książka dokumentuje okres przełomu zainicjowanego obradami Okrągłego Stołu i wyborami do Sejmu 4 czerwca 1989 r. i następujący po nich proces transformacji ustroju politycznego i gospodarczego Polski oraz towarzyszących mu przemian społecznych. Bez trudu można jednak rozpoznać na jej kartach Mazowieckiego-intelektualistę, człowieka konsekwentnie kierującego się wartościami zakorzenionymi w chrześcijaństwie, patriotę ukształtowanego doświadczeniami trudnego wieku dwudziestego i polityka europejskiego formatu. Choć już dziś można postawić tezę, że ten syn płockiego lekarza zajmie należne mu miejsce $\mathrm{w}$ historii przede wszystkim jako pierwszy premier III Rzeczypospolitej, ułomne byłyby wszelkie próby zarysowania jego postaci pomijające wcześniejszą biografię i drogę ideową, nierozłącznie splecioną ze skomplikowanymi dziejami Polski Ludowej. W tym względzie Rok 1989 i lata następne pozostają charakterystyczne, bo choć ukazują najnowsze dzieje Polski w wielu zróżnicowanych tekstach, nicią je spajającą jest właśnie system wyznawanych przez Tadeusza Mazowieckiego wartości, którym był wierny do końca. Nie pisze tu o swoich wcześniejszych latach prób wyszukiwania przestrzeni autonomii dla publicznej działalności katolików w Polsce Ludowej, dialogu przeżywającego iście kopernikański przewrót spowodowany Soborem Watykańskim II chrześcijaństwa ze współczesną kulturą czy nieco późniejszej ewolucji (będącej wynikiem realistycznej oceny sytuacji) skłaniającej go do podjęcia roli rzecznika rodzącej się opozycji, jest jednak oczywistością, że wcześniejsze etapy biografii przesądziły o ostatnim ćwierćwieczu. Symboliczny moment przyjazdu Bronisława Geremka i Tadeusza 
Mazowieckiego do ogarniętej strajkiem gdańskiej Stoczni im. Lenina w 1980 r. był początkiem drogi, która Mazowieckiego - katolickiego intelektualistę i publicystę - uczyniła politykiem. Na tej drodze - odwołując się do jego własnych słów o Krzysztofie Skubiszewskim - Mazowiecki dosięgnął wymiaru męża stanu (s. 488). Dyskretnie sygnalizuje to czytelnikowi już okładka omawianego tomu, w którego powściągliwej szacie edytorskiej ujęte w kolorach białym i czerwonym imię i nazwisko autora oraz historyczna data $\mathrm{z}$ tytułu wskazują, jak bardzo los osobisty Mazowieckiego splótł się z przełomowymi wydarzeniami najnowszej historii.

Ostatnią swoją książkę Tadeusz Mazowiecki rozpoczął ujmująco szczerym wyznaniem:

Wiele razy spotykałem się z pytaniem, dlaczego nie piszę pamiętników. Mówiono nawet, że to mój obowiązek. Niestety, nie umiałem się z tego wywiązać. Nie prowadziłem zapisków na bieżąco, nie potrafiłbym też tego nadrobić za pomocą wywiadu rzeki (s. 5).

Rzeczywiście, inaczej niż wielu jego współpracowników, członków rządu czy bliskich świadków przełomowych wydarzeń ${ }^{1}$, Mazowiecki nie złożył w ten sposób swego świadectwa. Jego relacje można zrekonstruować z licznych wywiadów prasowych, drukowanych m.in. w „Rzeczpospolitej”, „Polityce”, „Tygodniku Solidarność”, „Gazecie Wyborczej” czy „Nowej Europie Wschodniej”. Interesującym zarysem była jubileuszowa publikacja Tadeusz Mazowiecki - polityk trudnych czasów, pomyślana jako urodzinowy prezent od współpracowników i przyjaciół ${ }^{2}$. Autorzy uchronili się od schematów często spotykanych w tomach jubileuszowych, szkicując - jak to określiła Małgorzata Niezabitowska - ,obraz Polski z Tadeuszem Mazowieckim w tle”. Możemy być wdzięczni Mazowieckiemu za dopełnienie tej bibliografii ostatnią książką, która bynajmniej daleka od kompilacji, stanowi głos polemiki i napomnienia wobec życia publicznego, po ćwierćwieczu drastycznie niekiedy oddalającego się od założeń przyświecających pionierom polskiej zmiany.

Tadeusz Mazowiecki nie sugeruje Rokiem 1989... dającego się przełożyć na polityczną pragmatykę programu naprawy tego, co zostało utracone w fer-

${ }^{1}$ Patrz m.in.: L. Balcerowicz, 800 dni. Szok kontrolowany, Warszawa 1992; Gliniarz z 'Tygodnika'. Rozmowy z bytym ministrem spraw wewnętrznych Krzysztofem Kozłowskim, Warszawa 1991; W. Kuczyński Zwierzenia zausznika, Warszawa 1992; J. Kuroń, Moja zupa, Warszawa 1991; tegoż (z J. Żakowskim), Siedmiolatka czyli kto ukradt Polskę?, Wrocław 1997; L. Wałęsa, Droga do prawdy. Autobiografia, Warszawa 2008. Nieco inny charakter mają dotyczące tego okresu publikacje w popularnej formie wywiadu, m.in.: T. Torańska, My, Warszawa 1994; eadem, Byli, Warszawa 2006; J. Sadecki, Trzynastu. Premierzy wolnej Polski, Kraków 2009. Z kolei prób syntezy dziejów politycznych III Rzeczypospolitej dokonali historycy: Antoni Dudek, Andrzej Garlicki, Andrzej Friszke, Wojciech Roszkowski czy Andrzej Paczkowski.

${ }^{2}$ W. Kuczyński, Z. Psota (red.), Tadeusz Mazowiecki - polityk trudnych czasów, Warszawa 1997. 
worze transformacji ustrojowej. Zdaje sobie sprawę $\mathrm{z}$ bezprecedensowego charakteru zainicjowanej zmiany, jak i trwających do dziś procesów będących jej następstwem, na które nie było i nie ma prostych recept, a błędy bywają nieuniknione. Dlatego tym ważniejsze są elementarne zasady stanowiące wskazówkę dla polityków podejmujących wielkie wyzwania. Przypominając własne doświadczenia, świadom konsekwencji uchybień, zaniechań czy trudnych do przewidzenia skutków podejmowanych wówczas decyzji, wskazuje na konieczność powrotu do podstawowych, zdawałoby się - staroświeckich prawd o polityce. Jest wśród nich powtarzane często stwierdzenie o stylu walki politycznej, który niejednokrotnie liczy się bardziej od osiągania celów, czy zaczerpnięty z Maksa Webera imperatyw dążenia do tego, co niemożliwe, by osiągnąć to, co możliwe. Wyniesione z czasów PRL zasady okazały się zadziwiająco aktualne w realiach ,dziecięcej choroby” rozdrobnionego parlamentaryzmu czy w inicjatywach podejmowanych przez III Rzeczpospolitą na forum międzynarodowym.

Te same zasady znalazły zastosowanie $\mathrm{w}$ działaniach o diametralnie innej skali i wadze, gdy sprawujący mandat Specjalnego Sprawozdawcy Komisji Praw Człowieka ONZ były polski premier podszedł do swego zadania w sposób odbiegający od skostniałej natury oenzetowskiej machiny. W wywiadzie z 1995 r. Dawid Warszawski wspomina:

Kiedy pan został specjalnym sprawozdawcą, na giełdzie dziennikarskiej żartowaliśmy, że „zawdzięcza” to pan swojej reputacji „żółwia”. Że ONZ oczekiwała, iż pan co najwyżej powie, że wojna jest okropna, napisze jakiś raport i tyle. Tymczasem szybko stał się pan niewygodny nie tylko dla sprawców zbrodni, ale i dla ONZ-owskiej biurokracji (s. 288).

Osiemnaście raportów sporządzonych w ciągu trzyletniej misji to przede wszystkim drobiazgowy zapis rzetelnie potwierdzonych faktów. Raz jeszcze Warszawski:

Komendant zaprzeczał, a pan powiedział: ,Ja byłem więźniem, wiem, co to oznacza, niech pan to jeszcze raz sprawdzi”. Komendantowi szczęka opadła. Zdarzało mu się pewnie rozmawiać i z więźniami, i z dostojnikami, ale nigdy chyba nie rozmawiał z dostojnikiem, który wcześniej był więźniem (s. 300).

Wyrazem charakterystycznej dla Mazowieckiego konsekwencji było pełnienie tej misji wbrew obojętności opinii międzynarodowej aż do momentu, gdy spektakularne zrzeczenie się mandatu pozostało jedyną szansą przerwania letargu ONZ i sił pokojowych bezczynnych w obliczu ludobójstwa. „Walczyliśmy w Polsce $\mathrm{z}$ totalitarnym systemem, z nadzieją patrząc na Europę przyszłości. Jak można wierzyć w Europę jutra tworzoną przez dzieci tych ludzi, których dziś się opuszcza?" - pytał Sekretarza Generalnego ONZ w liście 
zawierającym zrzeczenie się mandatu Specjalnego Sprawozdawcy (s. 283). Trudno chyba o lepszy przykład wagi imponderabiliów (to ulubione słowo Jerzego Zawieyskiego, przejęte także przez Tadeusza Mazowieckiego) w zawikłanych realiach polityki.

Bałkański dramat jest w omawianej książce jedynym elementem przesuwającym narrację na szeroki plan relacji międzynarodowych. Inne wydarzenia rozgrywające się w sferze stosunków z Niemcami, Rosją czy procesu przygotowania Polski do integracji europejskiej pojawiają się tylko jako tło polskich przemian od schyłku lat osiemdziesiątych. Autor nie pominął jednak momentów i osobistości, które odcisnęły swój ślad na historii polskiej zmiany, bez których niemożliwa byłaby reorientacja polskiej polityki i osadzenie odradzającego się państwa w optymalnym położeniu międzynarodowym. Kategoryczne stwierdzenia, za pomocą których nawet z późniejszej perspektywy Mazowiecki relacjonuje swoje stanowisko wobec Niemiec w okresie jednoczenia dwóch państw za Odrą i działań na rzecz potwierdzenia ostatecznego charakteru polskiej granicy zachodniej nie pozostawia wątpliwości co do determinacji premiera. Miał jednak za partnera rozmów postać o podobnej charyzmie. Znaczną wartość źródłową ma przytoczony w książce zapis rozmowy telefonicznej przeprowadzonej 23 lutego 1990 r. z Helmutem Kohlem (s. 113-123), znakomicie oddający zarówno atmosferę czasu, jak i format osobowości obu szefów rządów. W książce napotkamy także innego Niemca i chrześcijanina, bez którego determinacji uboższe byłyby początki polsko-niemieckiej drogi do porozumienia - Güntera Särchena. Pisze Mazowiecki:

Doprawdy, trudno zrozumieć, czemu po 1989 roku nie sięgnięto po takich ludzi jak Särchen. Jeśli nawet było ich niewielu, tym bardziej byli cenni. Tymczasem po 1990 roku moi wysoko postawieni niemieccy rozmówcy o nazwiskach i znaczeniu takich ludzi jak Günter dowiadywali się... ode mnie. Niczego to zresztą nie zmieniało, bo wymagałoby wyobraźni i przekroczenia granic partyjnych establishmentów. I tak, po raz drugi, oficjalna historia zostawiła Güntera na boku (s. 468).

Jak istotna była wówczas umiejętność operowania na podobnej płaszczyźnie wartości, kultury czy nawet znajomości języka, przypominają inni bohaterowie przełomu przywołani na kartach Roku 1989 i lat następnych: Mieczysław Pszon czy Krzysztof Skubiszewski, którego już nawet sama osoba miała być czytelnym i jednoznacznym sygnałem zmiany w polskiej polityce zagranicznej. Mazowiecki zaświadcza, jak zdecydowanie musiał działać podczas formowania gabinetu, by szefem dyplomacji uczynić osobę niezwiązaną z odchodzącym porządkiem. To jeden w przykładów przypominających, że niekomunistyczny rząd powstawał w otoczeniu zarówno wewnętrznym, jak i sojuszy międzynarodowych, co do których należało się liczyć z niekoniecznie neutralnymi reakcjami, sam zaś premier spodziewał się, że choć wybija- 
jąca się na suwerenność, Polska będzie jeszcze dłuższy czas funkcjonować w dotychczasowym otoczeniu geopolitycznym. Obrazy spotkań przywódców Układu Warszawskiego z jesieni 1989 r. z udziałem premiera Tadeusza Mazowieckiego i ministra Krzysztofa Skubiszewskiego to istny chichot historii, wówczas jednak wcale nie tak oczywisty (s. 92nn, s. 148nn).

Najistotniejszą obok dokumentacyjnej i wspomnieniowej warstwą tej niejednorodnej, lecz fascynującej książki, jest refleksja na temat państwa oraz polityki. Przewija się bez mała od pierwszej do ostatniej strony, czy to w formie retrospektywnej, jako wskazania motywacji kierujących Mazowieckim jeszcze w okresie poprzedzającym przełom ustrojowy, a także podczas sprawowania funkcji Prezesa Rady Ministrów i później, czy też jako element jego wnikliwych i nierzadko bolesnych refleksji na temat stanu polskiej demokracji oraz sceny politycznej ostatniego ćwierćwiecza. Upływ czasu dzielący dzisiejszych czytelników od epoki rządu Mazowieckiego wymaga podkreślenia warunków, w jakich rozpoczynała się przebudowa ustroju i państwa. Gruzy nadziei po wprowadzeniu stanu wojennego i siedem straconych lat poprzedzających zmianę były - zdaniem autora - czasem dojrzewania przełomu: po stronie opozycji niemożliwe było porzucenie rozwiniętych aspiracji wolnościowych, po stronie władz zachodził ,zbiorowy grzech” wiary w możliwość odnowy po brutalnym złamaniu ruchu społecznego pierwszej „Solidarności” (s. 14). Premier przypomina specyfikę czasu, w którym może kulała polityka informacyjna, ale zmiany następowały bez nadmiernego ich rozgłaszania; na zarzut, że nie wzywał do wymiany kadr odpowiada:

Nie wzywałem do tego, ale po prostu to robiłem. Kiedyś na Radzie Ministrów minister przemysłu Tadeusz Syryjczyk powiedział, że dziennie jest wymienianych dwóch dyrektorów zakładów przemysłowych (s. 61).

Zgadza się z brakiem symbolicznej cezury wyznaczającej zmianę, ale i tu wskazuje na swe priorytety:

Pozostawałem pod wrażeniem ogromnego poparcia dla przemian. Nie sądziłem, że trzeba było upiększać je symbolicznymi gestami. Potem przyszły trudności, przede wszystkim polityczne (s. 62).

W innym miejscu pisze:

Tak, miałem świadomość tego [dekomunizacji państwa], choć właściwie nigdy tego tak nie nazwałem, bo uważałem, że w ogóle z powstaniem tego rządu zaczęła się już inna epoka (s. 65).

Skoro o początku nowej epoki mowa, trzeba zasygnalizować zamieszczony w książce esej „Sąd nad grubą kreską”, napisany z perspektywy narosłych 
wokół tego hasła nieporozumień i niezrozumienia, w którym autor nie przemilcza także krytycznych opinii cenionych przezeń osób, z jakimi przyszło mu się zmierzyć.

Zmiana oznaczała również podwyższenie wymagań:

Dotychczas mówiliśmy o niezbędności pluralizmu. Teraz trzeba ten pluralizm umieć praktykować. Dotychczas wszystko adresowaliśmy do przeciwników, teraz trzeba wartości, o których obecność w polityce walczyliśmy, przymierzać także do siebie (s. 180).

W tym stwierdzeniu, dla wielu zaabsorbowanych wówczas transformacją chyba dość zaskakującym, tkwi swoisty „grzech pierworodny” gwałtownie odzyskanej wolności, z którego konsekwencjami borykamy się do dziś. Echa jego trwania aż nazbyt są wyraźne w zgromadzonych w książce Mazowieckiego wypowiedziach pochodzących z różnych momentów ostatnich dekad. Formułował je najpierw z pozycji premiera czy lidera Unii Demokratycznej/ Unii Wolności, polityka zaangażowanego w przygotowanie Konstytucji RP, a wreszcie bez mała ojca założyciela III RP, którego wolny od doraźnych politycznych uwikłań głos wnosił do debaty publicznej ton napomnienia i zobowiązania. Gorzkim wyrzutem pobrzmiewa czytane dziś wystąpienie premiera z 25 maja 1990 r., kończące kampanię przed pierwszymi w pełni wolnymi wyborami - a były to wybory odrodzonego samorządu terytorialnego - zawierajęce kalendarz zmian niezbędnych dla dokończenia demokratycznej przebudowy państwa, wskazujący dwustulecie konstytucji trzeciomajowej jako możliwy termin wejścia w życie nowej konstytucji (s. 186). Pewnie słusznym usprawiedliwieniem po siedmiu latach było przypomnienie, że będąc premierem stwarzał fakty - za ważniejsze uznawał reformę systemu gospodarczego i politycznego i nie był w stanie zajmować się równocześnie konstytucją (s. 306). Nie sposób było oczekiwać konstytucji od nie w pełni demokratycznie wyłonionego Zgromadzenia Narodowego, a każdy, kto uświadomi sobie zakres i ogrom zmian wdrożonych przez urzędujący zaledwie szesnaście miesięcy gabinet, nie może go winić za odłożenie sprawy konstytucji.

Nie tylko opóźnienia (i demagogiczne, graniczące z absurdem ataki, o których wnet zapomnieli ich piewcy, korzystający z dobrodziejstw konstytucyjnej praktyki) związane z powstaniem konstytucji wywoływały coraz częstsze refleksje o odzyskanym, suwerennym państwie, któremu brakuje społecznej legitymizacji. Podział „my”-,oni” zachowywał swą żywotność, nie tylko utrudniając uznanie państwa za własne, ale i wpływając na jego rzeczywistą siłę. Przenikliwe (by nie powiedzieć prorocze) były tezy Tadeusza Mazowieckiego z 1991 r. o trudnościach budowy demokracji: nieistnienie komunizmu nie oznacza jeszcze demokracji, a tworzenia społeczeństwa obywatelskiego nie da się oddzielić od zmiany stosunku do własnego państwa (s. 257-261). 
Jedenaście lat później nadal piętnował brak w Polsce świadomości, że państwo stanowi dobro wspólne i napominał, że konieczne jest reagowanie, gdy demokracja zaczyna marnieć. Wyrachowane sojusze, w które zaczęła się wikłać założona przez niego formacja w polityce krajowej oraz opuszczenie przez nią Europejskiej Partii Ludowej przesądziło o wystąpieniu Mazowieckiego z partii. Tonem patriarchy przypominał:

W wolności i demokracji, przy wszystkich jej wielkich i dobrych stronach, tkwią także możliwości autodestrukcyjne. Jeżeli wolności i demokracji nie towarzyszy odpowiednie poczucie odpowiedzialności za wspólne dobro, za kształt życia zbiorowego, za rzeczywiste, a nie tylko formalne poszanowanie rządzących nimi reguł, to zwłaszcza w pewnych sytuacjach może następować autodestrukcja demokracji pociągająca za sobą autodestrukcję wolności (s. 352).

Powodów do zmartwień nie przestawały dostarczać skłócone elity polityczne, a także przyzwalająca apatia: ,społeczeństwo zdolne tylko do narzekania nie przeciwstawi się erozji demokracji ani nie będzie społeczeństwem rozwoju" (s. 372). Próby kwestionowania III RP, dezawuowania jej dokonań i wprowadzania kolejnego „nowego początku” Tadeusz Mazowiecki oceniał nie tylko w kategoriach dynamiki politycznej i obrony instytucji oraz dokonań, które osobiście współtworzył. Niepokoiło go zawarte w tych działaniach kwestionowanie samej państwowości, niszczące nadal kruchą relację obywateli do własnego państwa (s. 383). Istnienie takiego niebezpieczeństwa znajduje potwierdzenie $\mathrm{w}$ towarzyszących wielu obserwatorom polskiej sceny politycznej odczuciach bezradności, paraliżującej niemożności i zagubienia. Trafnie Mazowiecki przywołał wniosek Alexisa de Tocqueville'a z pracy O demokracji w Ameryce:

Należy więc zwalczać nie tyle anarchię czy despotyzm, ile apatię, która może doprowadzić zarówno do jednej, jak i do drugiego (s. 384-385).

Postępująca równolegle do dziejów odrodzonej Rzeczypospolitej lektura książki (choć autor nie zachowuje konsekwentnie chronologii w układzie reedytowanych w niej tekstów) może nasunąć przypuszczenie, że im bliżej współczesności, bardziej intensywnie daje o sobie znać żyłka Tadeusza Mazowieckiego-publicysty. Tak jednak nie jest. Jest to manifest wielkiego demokraty i państwowca, którego głos uwiarygodnia osobiste doświadczenie opisywanego ćwierćwiecza. Pytany w 2000 r. o „normalność” Sojuszu Lewicy Demokratycznej odpark:

Bądźmy sprawiedliwi. Czołówka PZPR odeszła z życia politycznego. SLD w 1993 roku wygrał wybory, demagogicznie krytykując konieczne reformy, które myśmy mieli odwagę podjąć, ale mimo wszystko po dojściu do władzy konty- 
nuował je. (...) Czy partii, na którą zamierza głosować czterdzieści procent społeczeństwa, można odmówić tego miana? (s. 335-336).

Daleki od doktrynerstwa Mazowiecki zachowuje przy tym silne przywiązanie do wyznawanych wartości, które bez ostentacji praktykuje - nie dla etykietki, lecz jako praktyczne wskazówki działania.

W różnych sytuacjach mam rozmaite graniczne przywiązania i dlatego nie lubię przyporządkowywać swoich poglądów w sposób nadmiernie prosty i naginać się do schematów (...). Podziały ideologiczne wyglądają inaczej w historii doktryn, inaczej natomiast $\mathrm{w}$ okresie tak wielkiej transformacji i kiedy ma się odpowiadać za podejmowane decyzje w warunkach bardzo ograniczonych możliwości (s. 235).

Trzeba jeszcze odnotować wątek dotyczący roli Kościoła w Polsce. Nie jest on w książce szczególnie wyeksponowany, pojawia się tylko w kontekście relacji z państwem oraz roli w polskich przemianach. Różnica w wypowiedziach Tadeusza Mazowieckiego pochodzących z początku transformacji oraz z ostatnich lat jest jednak kolosalna. Niezmienna pozostała ocena wypracowanych ram prawnych relacji państwo-Kościół, stwarzających przestrzeń wystarczającą zarówno dla pluralizmu i demokratycznego porządku państwowego, jak i dla działalności wszystkich Kościołów i związków wyznaniowych. W wypowiedzi z 1990 r. premier zawarł przekonanie o możliwości znalezienia w polskim katolicyzmie „wystarczająco dużo sił, otwartości, tolerancji w stosunku do innych ludzi, że właśnie o takie widzenie roli Kościoła będzie oparty stosunek do instytucji państwowych. Krótko mówiąc, powinny to być stosunki dobre i suwerenne” (s. 210). Wprawdzie „warunki brzegowe" zawarte w aktach ustrojowych nie uległy zasadniczym modyfikacjom, ale trudno było w ostatnich latach o podobny optymizm. Mazowiecki był świadom niepokojących symptomów narastania zjawisk, którym Kościół mógłby zaradzić - powrotu starych stereotypów, języka oskarżeń czy nienawiści. Wcześnie pojawiły się rysy na monolicie, zlekceważone czy niewłaściwie zdiagnozowane:

Kiedy w czasie jednej i drugiej kampanii mówiłem biskupom, że na zebraniach przedwyborczych młodzi ludzie występują z krytyką Kościoła i że jest to symptom czegoś istotnego, nad czym trzeba się zastanowić, to wszyscy, ale dosłownie wszyscy biskupi, z którymi rozmawiałem, odpowiadali, że to jest inspirowane (s. 235).

Współtwórca „Więzi” wierzył w siły drzemiące w otwartym katolicyzmie, chrześcijaństwie odnowionym Soborem Watykańskim II oraz pontyfikatami papieży od Jana XXIII po Benedykta XVI (a jak wiadomo z innych relacji, 
także Franciszka), sam czerpał wiele ze spuścizny papieża Polaka. Nie uchybiało to krytyce niewłaściwych form zaangażowania ludzi Kościoła w polityce, braku rozumienia demokracji, przede wszystkim zaś niewykorzystania ogromu kościelnego autorytetu dla łagodzenia sporów oraz wskazywania dróg pojednania polsko-polskiego. Zaniechania te kontrastowały z wcześniejszą postawą hierarchii, wspierającej niełatwy dialog z władzami prowadzący do przełomu $1989 \mathrm{r}$.

Błędem było postrzeganie liberalnej demokracji jako takiego samego zagrożenia dla religii jak komunizm. (...) Kościół, obawiając się laicyzacji, fałszywie zdiagnozował źródło zagrożenia. Za wroga uznano laicką inteligencję czy różnorodne postoświeceniowe systemy filozoficzne, tymczasem prawdziwym zagrożeniem jest to, co Anna Morawska nazwała kiedyś „tramwajowym ateizmem”, a co dzisiaj trafniej byłoby chyba określić jako „telewizyjny agnostycyzm” a więc odzieranie życia z głębszych wartości, nastawienie na płytką konsumpcję (s. 337).

Dramatyczna to konstatacja, jeśli uświadomimy sobie, że zarówno tak zdiagnozowane braki formacji chrześcijańskiej, jak i niedostatki etosu obywatelskiego odnoszą się do tych samych ludzi mieszkających między Odrą a Bugiem. Trudno zaakceptować, że Kościół i państwo podążają równoległą drogą, nie zauważając niewykorzystanych przestrzeni współpracy.

Wbrew wielu wskazanym na kartach książki niedostatkom polskiej rzeczywistości roku 1989 i lat następnych, Tadeusz Mazowiecki daje wyraz głębokiemu przekonaniu o pozytywnym bilansie ćwierćwiecza i uniwersalnym wymiarze wartości, które mu przyświecały w służbie publicznej. I wcale nie ulega opinii, że jego sposób działania przynależy do zamkniętej epoki:

Teraz rządzą polityką inne prawa. Może. Ale może też późne wnuki odkryją znaczenie i smak polityki, w której liczy się nie tyle władza dla władzy, lecz pociąga do niej służenie dobru wspólnemu i wpływanie bardziej na bieg historii niż na opinie następnego dnia (s. 475). 
